\title{
Chronic lead exposure reduces doublecortin- expressing immature neurons in young adult guinea pig cerebral cortex
}

\author{
JuFang Huang ${ }^{1+}$, Kai Huang ${ }^{1,2+}$, Lei Shang ${ }^{1}$, Hui Wang ${ }^{1}$, Mengqi Zhang ${ }^{3}$, Chun-Ling Fan', Dan Chen',
} Xiaoxin Yan $^{1 *}$ and Kun Xiong ${ }^{1 *}$

\begin{abstract}
Background: Chronic lead $(\mathrm{Pb})$ poisoning remains an environmental risk especially for the pediatric population, and it may affect brain development. Immature neurons expressing doublecortin (DCX+) exist around cortical layer II in various mammals, including adult guinea pigs and humans. Using young adult guinea pigs as an experimental model, the present study explored if chronic Pb exposure affects cortical DCX + immature neurons and those around the subventricular and subgranular zones (SVZ, SGZ).

Results: Two month-old guinea pigs were treated with $0.2 \%$ lead acetate in drinking water for 2, 4 and 6 months. Blood Pb levels in these animals reached $10.27 \pm 0.62,16.25 \pm 0.78$ and $19.03 \pm 0.86 \mu \mathrm{g} / \mathrm{dL}$ at the above time points, respectively, relative to $\sim 3 \mu \mathrm{g} / \mathrm{dL}$ in vehicle controls. The density of $\mathrm{DCX}+$ neurons was significantly reduced around cortical layer II, SVZ and SGZ in Pb-treated animals surviving 4 and 6 months relative to controls.

Bromodeoxyuridine (BrdU) pulse-chasing studies failed to find cellular colocalization of this DNA synthesis indicator in DCX + cells around layer II in Pb-treated and control animals. These cortical immature neurons were not found to coexist with active caspase-3 or Fluoro-Jade C labeling.

Conclusion: Chronic Pb exposure can lead to significant reduction in the number of the immature neurons around cortical layer II and in the conventional neurogenic sites in young adult guinea pigs. No direct evidence could be identified to link the reduced cortical DCX expression with alteration in local neurogenesis or neuronal death.
\end{abstract}

Keywords: Immature neurons, Lead exposure, Doublecortin, Neocortex, Guinea pigs

\section{Background}

As one of the ubiquitously polluted heavy metals in ecosystem and modern industry, lead $(\mathrm{Pb})$ may enter human body via many routes including airway, water and fo od $[1,2]$. Pb exposure many cause chronic central and peripheral nerve damages in humans at all ages, with more concerns for the pediatric population. Neurological consequences of $\mathrm{Pb}$ poison in children are reported to include reduction in IQ and learning/ memory capability, hearing and language impairments and certain neuropsychological abnormalities [3-11].

\footnotetext{
*Correspondence: yanxiaoxin@csu.edu.cn; xiongkun2001@163.com

${ }^{\dagger}$ Equal contributors

'Department of Anatomy and Neurobiology, Central South University School of Basic Medical Sciences, Changsha, Hunan 410013, China

Full list of author information is available at the end of the article
}

The cellular mechanism underlying $\mathrm{Pb}$ overexposureinduced neurotoxicity in the central nervous system is complex. Of interest, recent studies have shown that chronic low level $\mathrm{Pb}$ exposure may inhibit neurogenesis in the hippocampal formation and affect the differentiation/maturation of the newly-generated granule cells, which may be relevant to behavioral and cognitive impairments associated with $\mathrm{Pb}$ poisoning [12-14].

We and others have identified a novel group of immature neurons located around layer II of the adult cerebral cortex in relatively large mammals including guinea pigs, cats, rabbits, nonhuman primates and humans; these cells express doublecortin (DCX+) and other typical immature neuronal markers [15-24]. These cortical immature neurons are more numerous in young relative to more mature animals and appear to be involved in 
neuronal structural plasticity [17-19,25]. More recently, these immature neurons are documented in brains of human infants and children $[21,25,26]$. The present study attempted to determine whether these immature cortical neurons were vulnerable to chronic $\mathrm{Pb}$ exposure using young adult guinea pigs as an experimental model. Data were also compared to DCX + neurons in the subventricular zone (SVZ) and subgranular zone (SGZ) that relate to adult neurogenesis [24]. Efforts were also taken to explore if changes in cortical DCX expression overtly relate to local neurogenesis and neuronal death.

\section{Results}

\section{Elevation of blood Pb levels following chronic lead exposure}

Blood $\mathrm{Pb}$ levels were increased to $10.27 \pm 0.62 \mu \mathrm{g} / \mathrm{dL}$ in the 2 month $\mathrm{Pb}$ exposure group, to $16.25 \pm 0.78 \mu \mathrm{g} / \mathrm{dL}$ in the 4 month surviving group, and to $19.03 \pm 0.86 \mu \mathrm{g} / \mathrm{dL}$ in the 6 month surviving group. Among the age-matched control groups, blood Pb levels were $2.65 \pm 0.21 \mu \mathrm{g} / \mathrm{dL}$, $3.01 \pm 0.25 \mu \mathrm{g} / \mathrm{dL}, 3.13 \pm 0.31 \mu \mathrm{g} / \mathrm{dL}$, respectively. Statistically, blood $\mathrm{Pb}$ levels elevated in the animal groups treated with lead acetate in a time-dependent manner at the 3 time points relative to age-matched control groups, with posthoc tests indicating no differences among the control groups (Figure 1).

\section{Decline in DCX + cells in cortical layer II following chronic lead exposure}

DCX + cells were found in multiple cortical areas of the guinea pigs, including $\mathrm{Pb}$ exposure and age-matched control groups, as with previous reports $[17,20]$. Thus,

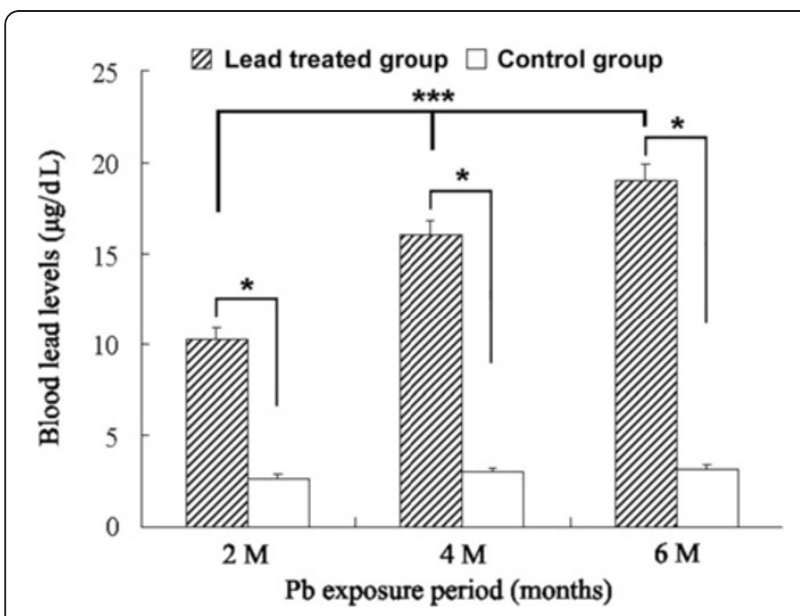

Figure 1 Elevation of blood $\mathrm{Pb}$ levels in adult guinea pigs subjected to $\mathrm{Pb}$ exposure for 2, 4 and 6 months. Each bar represents the mean \pm SEM. ${ }^{* * *}: p<0.01$ among different $\mathrm{Pb}$ exposure time groups, $\mathrm{F}=103.352$, one-way ANOVA. *: $p<0.05$ between $\mathrm{Pb}$ exposure group vs same age-matched control group (post hoc tests). distinctly labeled DCX + cells with varying sizes and morphology formed a cellular band deep to layer I over the frontal, parietal, temporal and occipital cortical areas. By visual comparison DCX + cells in $\mathrm{Pb}$ exposure groups appeared to be reduced over all cortical areas in animals survived 4 and 6 months, but not in those survived for 2 months, relative to age-matched control groups (Figures 2, 3 and 4).

The densities of DCX immunoreactive cells were quantified in the frontal, parietal, temporal and occipital areas. Cell counting in the frontal cortex was performed on 3 equally-spaced $(720 \mu \mathrm{m}$ apart) coronal sections passing the striatum, with the first one at the level of the first appearance of the anterior horn. Cell counting in the parietal and temporal cortices were conducted in 3 equally-spaced (also $720 \mu \mathrm{m}$ apart) coronal sections around the "temporal pole" or the widest portion of the cerebrum, using the piriform fissure and lateral sulcus as landmarks for dividing the temporal and parietal areas [17]. Cell counting in the occipital cortex was carried out in 3 equally-spaced (720 $\mu \mathrm{m}$ apart) coronal sections passing the superior colliculus. Compared to agematched control groups, the density of the entire DCX + cell population around layer II was significantly declined in the lead-treated groups surviving 4 and 6 months surviving groups over the parietal (Figure 5A), temporal (Figure 5B), frontal (Figure 5C) and occipital (Figure 5D) cortices. However, no significant reductions were detected in these areas at 2 months following $\mathrm{Pb}$ dosing relative to control (Figure 5A-D). The densitometric analyses on DCX + cells based on somal sizes indicated that the smaller $(<10 \mu \mathrm{m}$ in longer somal diameter $)$ $\mathrm{DCX}+$ cells were decreased more significantly relative to larger ones $(>10 \mu \mathrm{m}$ in longer somal diameter) in all of the 4 analyzed areas (Figure 6).

\section{Decline in DCX + cells in the SVZ and SGZ following chronic lead exposure}

Consistent with previous reports regarding lead-induced decrease in adult neurogenesis in small laboratory rodents [12-14], the present study also noted a significant decline of DCX + neurons in the subventricular zone (SVZ) and subgranular zone (SGZ) in animals subjected to chronic lead exposure relative to controls (Figure 7A-F). Thus, there was a dramatic loss of DCX + cells around the SVZ in the Pb-treated animals surviving 2, 4 and 6 months relative to controls. The same situation existed in the dentate gyrus wherein DCX + cells at the SGZ were apparently reduced in the $\mathrm{Pb}$ treated relative to control guinea pigs (Figure 7G-L). Because DCX + cells were densely packed in the SVZ and SGZ, an analysis was carried by simply using the optic density of labeling along the SVZ and SGZ. The intensity of DCX immunoreactivity was reduced up to $50 \%$ 


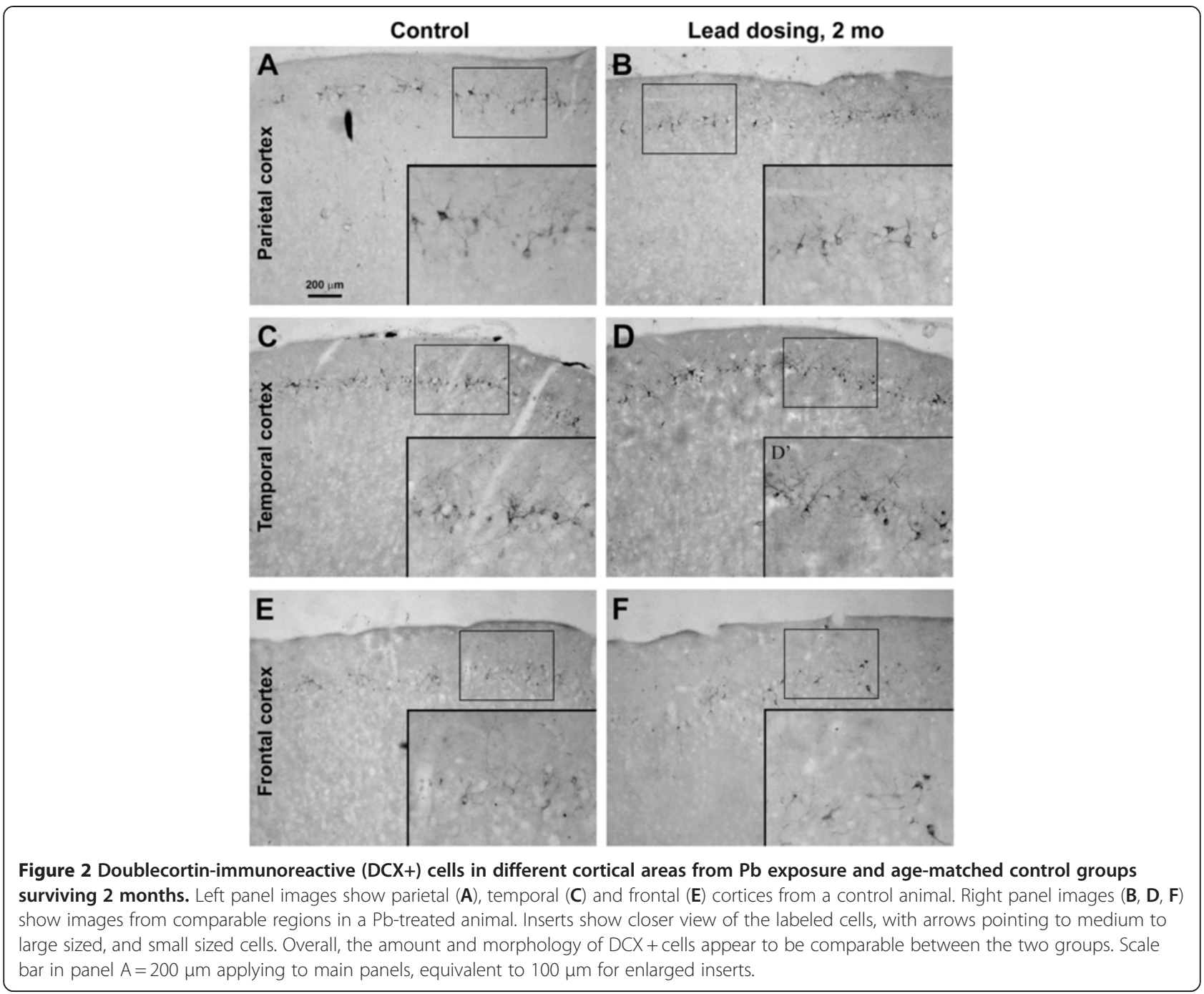

( 2 months) to $80 \%$ (4 and 6 months) in these two areas in the $\mathrm{Pb}$-treated relative to controls (with $P<0.01$ between the experimental and control groups at all time points) (quantification not shown).

\section{Lack of colocalization of BrdU in cortical DCX + neurons}

Recently studies have shown that the DCX + immature neurons around layer II could only occasionally be identified to colocalize with BrdU after pulse-chase administration of this DNA synthesis marker [27-32]. In the present study, double immunofluorescence was performed 2 and 4 months after BrdU injection. No clear BrdU colocalization with DCX or NeuN (data not shown) was found in either the Pb-treated guinea pigs or control animals in the 4 and 6 months surviving groups (Figure 8A-C). At both time points, singly labeled BrdU-containing cells were present in the superficial cortex, mostly over layers I and II (Figure 8A-C).
Lack of active caspase- 3 and fluoro-jade $\mathrm{C}$ labeling in cortical DCX + neurons

Active caspase- 3 and Fluoro-Jade $C$ labelings are used to detect apoptosis and cell injury or death under various conditions [33,34]. To explore if the reduction of $\mathrm{DCX}+$ cells in Pb-treated animals was overtly associated with cell death, we examined the expression of active caspase- 3 in the cortex by single or double labeling. Nuclear profiles were occasionally labeled in the cortex from $\mathrm{Pb}$-treated or control brains using an antibody that detect in situ caspase-3 activation [35]. Double immunofluorescence failed to find clear colocalization of active caspase- 3 in any DCX + cells around layer II (Figure 8D-G). In Fluoro-Jade $\mathrm{C}$ stain, labeled cells were occasionally encountered in the cortex in $\mathrm{Pb}$-treated guinea pigs. No clear colocalization of Fluoro-Jade $\mathrm{C}$ and DCX was detected (Figure $8 \mathrm{H}-\mathrm{J}$ ). As a positive assay control, Fluoro-Jade $\mathrm{C}$ labeled cells were found in the rat retina $24 \mathrm{~h}$ following induction of acute intraocular 


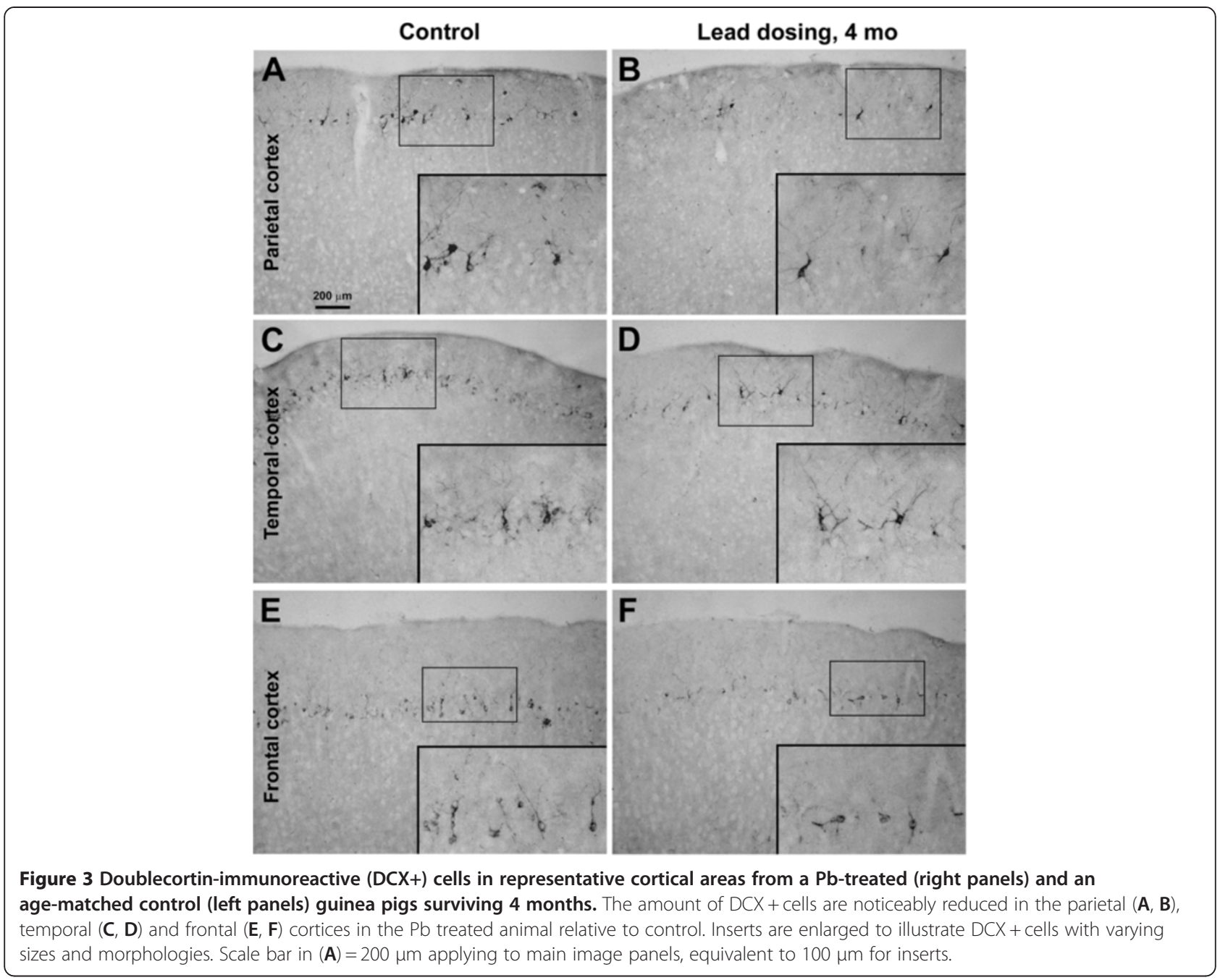

hypotension [36], whereas no labeling existed in normal rat retina (Figure $8 \mathrm{~K}-\mathrm{P}$ ).

\section{Discussion}

For centuries $\mathrm{Pb}$ poisoning remains an environmental risk for human health in all societies $[1,2,37,38]$, and its deleterious impact on central nervous system of children is well documented but of particular medical concern [3-11]. Children are more vulnerable to $\mathrm{Pb}$ exposure than adults for many potential reasons, including their exposure to $\mathrm{Pb}$ is favored by the habit of eating/chewing non-nutritive materials (pica habits); a child's intestine absorbs $\mathrm{Pb}$ much faster than that of an adult. Another reason is that their blood-brain barrier (BBB) is not completely mature [3,6,37-39]. Blood Pb levels at or over $10-20 \mu \mathrm{g} / \mathrm{dL}$ in children are generally considered to cause debilitating effects on brain structure and function, manifested by neurobehavioral, learning and cognitive abnormalities [37-39]. However, recent studies have shown intellectual impairment in children with blood $\mathrm{Pb}$ levels below $10 \mu \mathrm{g} / \mathrm{dL}$ [40,41]. For adults, high Pb levels may penetrate into the brain by accumulating on the mature $\mathrm{BBB}$ and/or altering its functional competence [42]. In the present study, blood $\mathrm{Pb}$ concentrations in the experimental guinea pigs have reached over $10 \mu \mathrm{g} / \mathrm{dL}$, therefore, are above the threshold levels that would cause neurotoxicity in rats and humans[12-14,39-41].

Overall, the mechanism(s) underscoring Pb-induced neurotoxicity in immature and adult brains appear to be complex, and may involve many aspects including oxidative stress, apoptosis, calcium homeostasis disruption and deregulation of cell signaling [42-49]. As one of the potential mechanistic concerns of $\mathrm{Pb}$-induced neurotoxicity in the developing brain, several research groups have reported that chronic low level $\mathrm{Pb}$ exposure inhibit adult neurogenesis in the small laboratory rodents [12-14], which may contribute to behavioral and cognitive impairments. Consistent with these reports, we have observed a dramatic loss of DCX + neurons in both the SVZ and SGZ in young adult guinea pigs. 

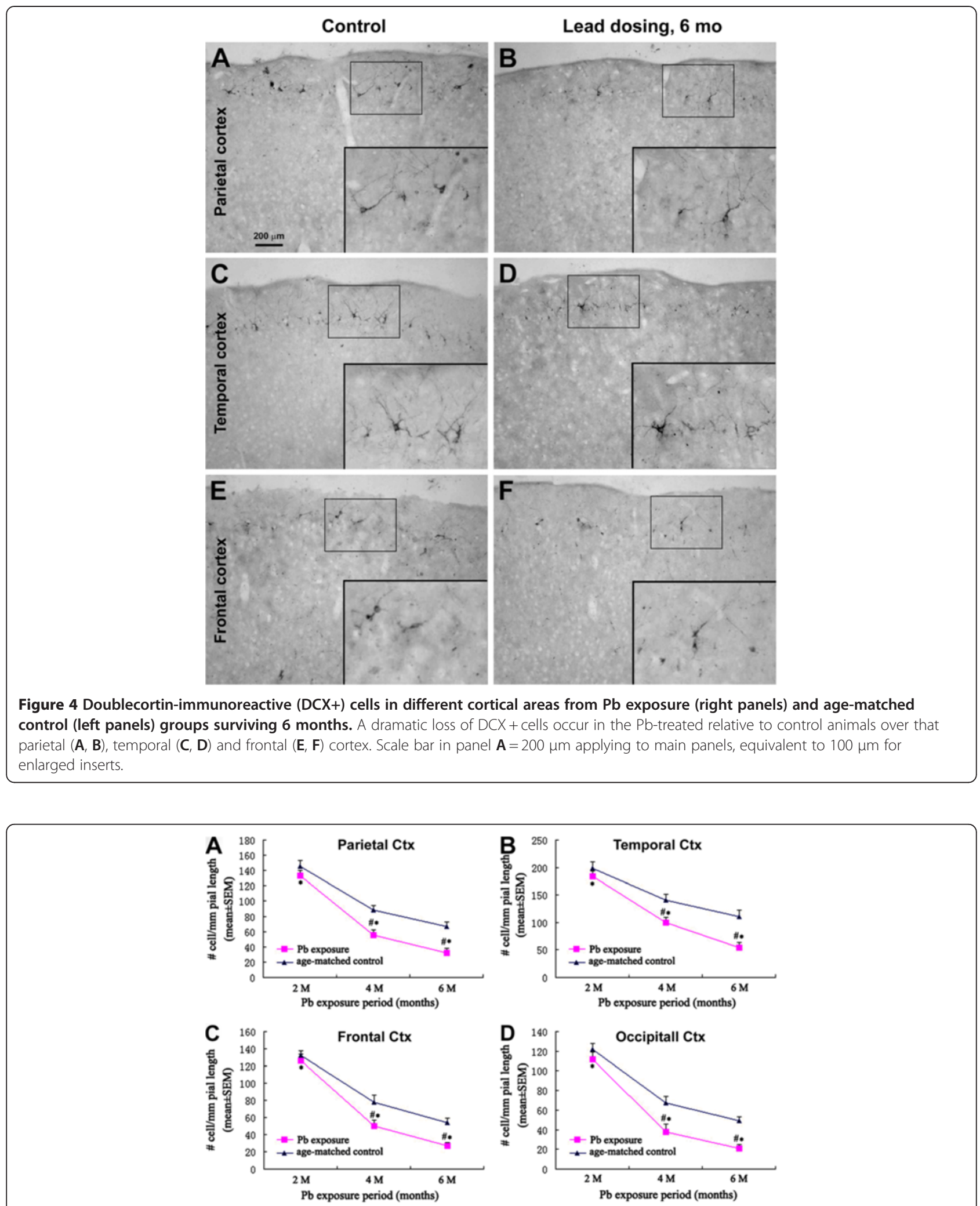

Figure 5 Densitometric data showing a time-related decline of doublecortin-immunoreactive (DCX+) cells, expressed as number of cells per $1 \mathrm{~mm}$ pial distance, in different cortical areas from $\mathrm{Pb}$ exposure relative to age-matched control group guinea pigs. A: parietal cortex; B: temporal cortex; C: frontal cortex; D: occipital cortex. Each bar represents the mean \pm SEM. \#: $p<0.05$ for Pb exposure vs age-matched control groups; *: $p<0.05$ among different $\mathrm{Pb}$ exposure time groups, $\mathrm{F}^{\mathrm{a}}=99.269, \mathrm{~F}^{\mathrm{b}}=100.500, \mathrm{~F}^{\mathrm{c}}=219.743, \mathrm{~F}^{\mathrm{d}}=105.450$. 

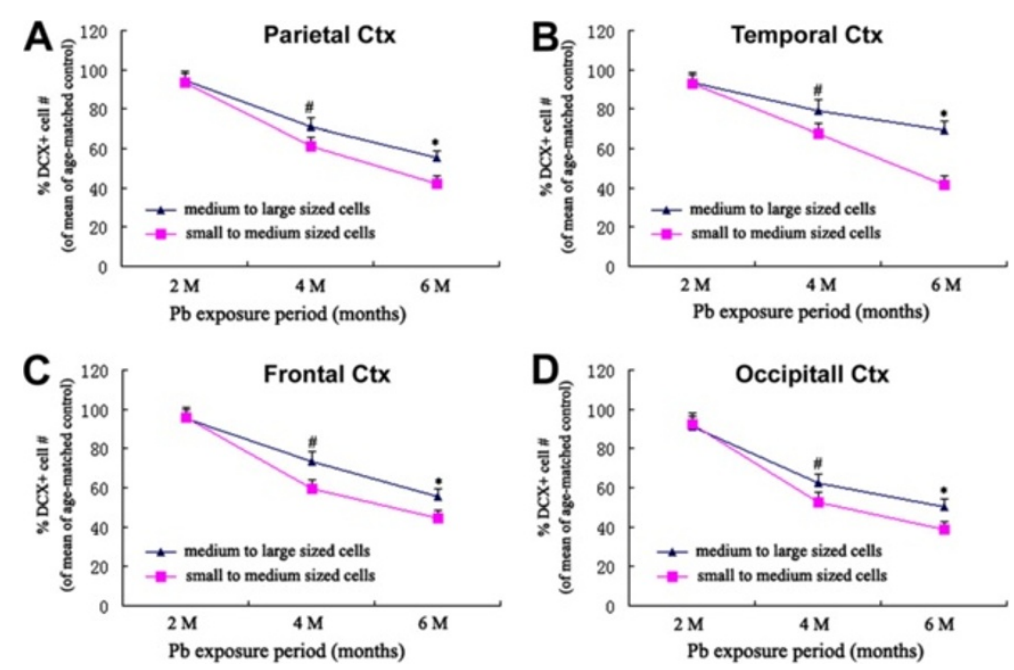

Figure 6 Line graphs showing the extent of reduction (\% of control levels) of smaller (blue) relative to larger (purple) doublecortin-immunoreactive ( $\mathrm{DCX}+$ ) cells in Pb-treated guinea pigs over the parietal (A), temporal (B), frontal (C) and occipital (D) cortices surviving 2, 4 and 6 months. Statistic differences exist between of the two cell groups at 4 and 6 months surviving points in all analyzed areas. \#: $p<0.05 ;$; : $p<0.01$.

In general, the hippocampal formation is functionally related to behavioral and cognitive activities such as memory and learning. However, the neocortex plays an increasingly critical role in cognition in mammals during evolution in parallel with cortical expansion and the development of complicated network systems [18-23]. Several research groups (including us) have independently described the presence of DCX + cells around cortical layer II in different adult mammalian species including guinea pigs, cats, non-human primates and
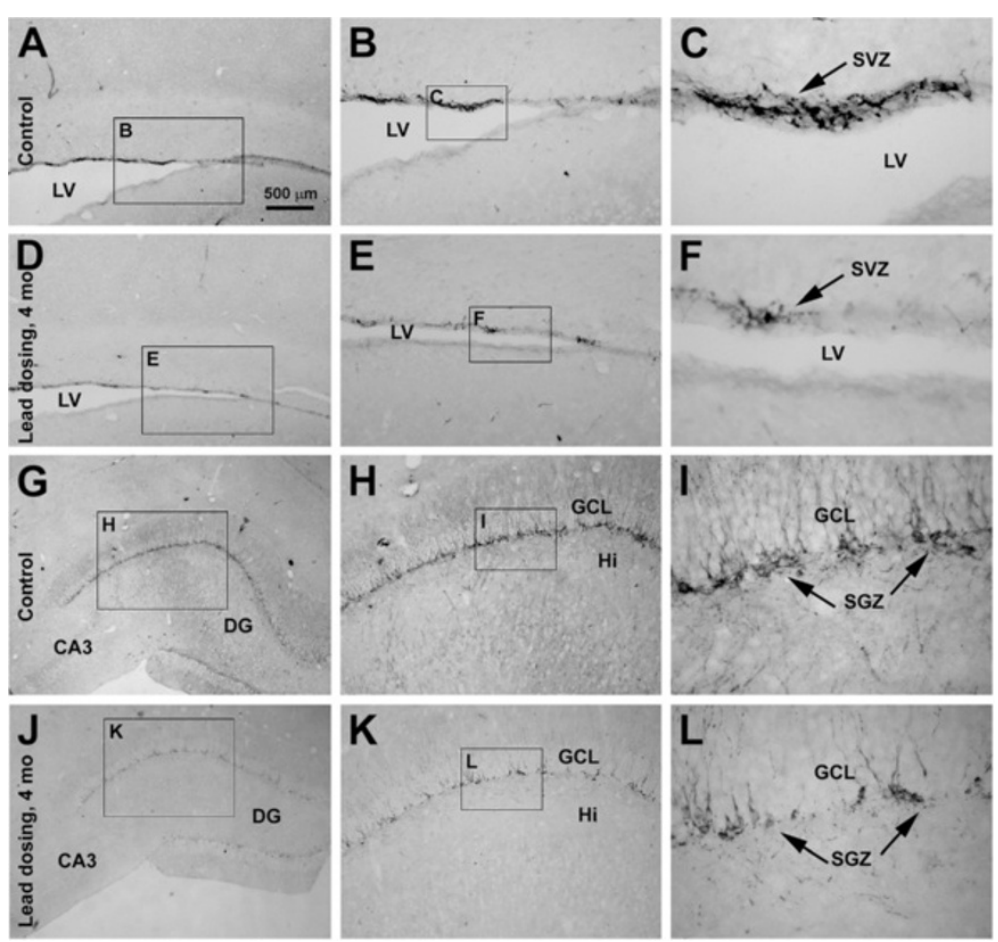

Figure 7 Representative data showing doublecortin-immunoreactive (DCX+) cells in the subventricular zone (SVZ) (A-F) and subgranular zone (SGZ) (G-L) in age-matched control (A-C; G-I) compared to Pb-treated (D-F; J-L) animals surviving 4 months. Framed areas in left panel images are sequentially enlarged as middle and right panel images. Scale bar in $(A)=200 \mu \mathrm{m}$ applying to left panels; equal to $200 \mu \mathrm{m}$ for middle panels and $50 \mu \mathrm{m}$ for right panels. 

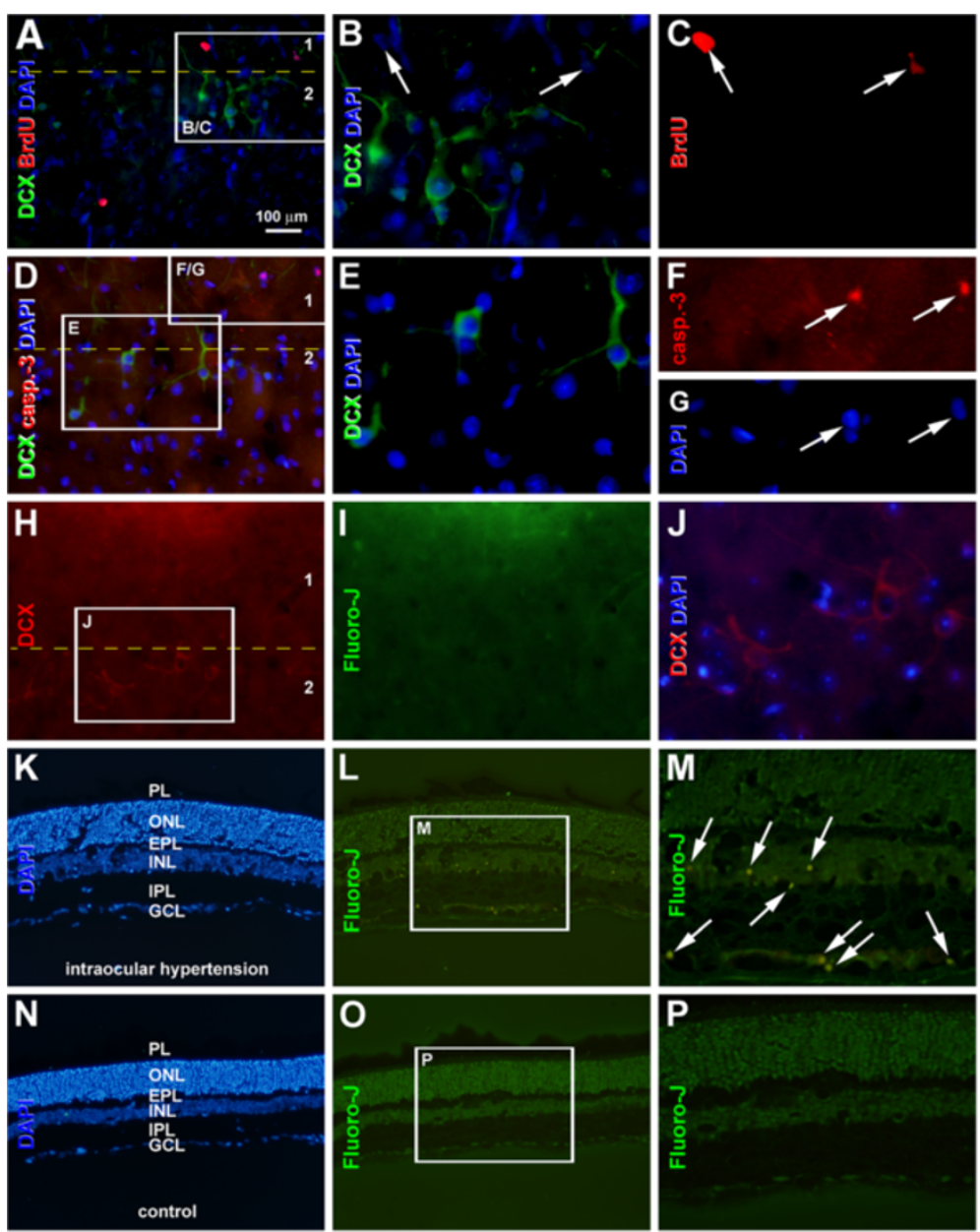

Figure 8 Representative data showing that doublecortin-immunoreactive (DCX+) cells around neocortical layer II in Pb-treated animals surviving 6 months do not colocalize with BrdU (A-C), active caspase-3 (D-G) or Fluoro-Jade C labeling (H-J). Markers and fluorescent channels are indicated on the left of each panel. Note that BrdU labeled cells (arrows) are present in layer I and upper III (A, C). Nuclei labeled for active caspase-3 are occasionally seen in layer I (D, F, and $\mathbf{G})$. Fluoro-Jade C labeled cells are rarely detected in the cortex (H-J) or normal rat retina (N-P). In contrast, they are found in the rat retina $24 \mathrm{~h}$ after intraocular hypotension (K-M). PL: photoreceptor layer; ONL: outer nuclear layer; EPL: external plexiform layer; INL: inner nuclear layer; IPL: inner plexiform layer; GCL: ganglion cell layer. Scale bar=100 $\mu$ m in A applying to $\mathbf{D}, \mathbf{H}, \mathbf{I}, \mathbf{K}, \mathbf{L}, \mathbf{N}$ and $\mathbf{O}$; equal to $50 \mu \mathrm{m}$ for $\mathbf{B}, \mathbf{C}, \mathbf{E}-\mathbf{G}, \mathbf{J}, \mathbf{M}$ and $\mathbf{P}$.

humans [15-26]. While the origin, fate and developmental trajectory of these cells remain to be further characterized [27-32,50], these cells can be activated by novel environmental exploration [31], which suggests that they might be involved in cortical network activity under physiological conditions. Our present results show that $\mathrm{DCX}+$ cells in different cortical areas in young adult guinea pigs decrease after treatment with $0.2 \%$ lead acetate for 4 and 6 months. Thus, chronic $\mathrm{Pb}$ exposure can result in remarkable loss of immature neurons in broad neocortical areas. Further, our present analysis also shows that loss of smaller sized DCX + cells appears more significantly relative to larger sized ones. DCX + cells with a larger somal size and more developed neuronal processes often co-localize with the neuron-specific nuclear protein $(\mathrm{NeuN})$, a mature neuronal marker
$[17,18,24,30,32,50]$. Thus, it appears that the smaller $\mathrm{DCX}+$ cells with a less mature phenotype may be more sensitive to $\mathrm{Pb}$ exposure. Because these small-sized neurons are more common than the large-sized ones in young mammals, $\mathrm{Pb}$ pollution could significantly impact cerebral neuronal development in children.

Hypothetically, reduction of DCX + cortical immature neurons in $\mathrm{Pb}$-treated animals could be resulted from loss of cells or decline in DCX expression. The former condition could be a consequence of reduced cell genesis and/or increased cell death. It is currently controversial as to whether layer II DCX + immature are or can be generated in postnatal life due to inconsistent BrdU birth-dating data [27-32,50]. In this study we could not find a clear colocalization of BrdU in cortical DCX + neurons at 2 and 4 months after BrdU injection. The 
lack of active caspase- 3 and Fluoro-Jade-C colocalization indicates that $\mathrm{DCX}+$ cortical cells in $\mathrm{Pb}$-treated guinea pigs are not overtly associated with apoptotic death, nor do they appear apparently injured.

\section{Conclusions}

This study demonstrates that $\mathrm{Pb}$ exposure induces a decline of DCX-expressing immature neurons in the neocortex as well as in the established neurogenic sites in adult guinea pigs, with a greater effect seen in the relatively small-sized subpopulation of the cells in the cortex. The findings from this study point to a potential new cellular substrate in mammalian cerebrum that would be expected to be vulnerable to chronic $\mathrm{Pb}$ exposure and toxicity in the pediatric population.

\section{Methods}

\section{Animals}

Thirty-six 2-month-old male guinea pigs weighing 300$350 \mathrm{~g}$ were used in the present study. All animals were housed in acrylic box cages and freely accessible to rodent chow and water. Animals were maintained under conditions of constant temperature $\left(25{ }^{\circ} \mathrm{C}\right)$, humidity $(50 \pm 10 \%)$ and lighting cycle $(12: 12 \mathrm{~h})$. Rat retinal sections from another study involving experimental glaucoma were used for assay control. All experimental procedures used in the present study were approved by the Animal Ethics Committee of Xiangya School of Medicine, Central South University, in accordance with the experimental animal use and welfare requirements set by the Ministry of Health of China as well as the NIH guidelines for use and care of laboratory animals.

\section{Chronic lead exposure and BrdU injection}

Eighteen animals were used as $\mathrm{Pb}$ exposure groups, and they received $0.2 \%$ lead acetate in drinking water for 2 , 4 and 6 months, respectively $(n=6 /$ time point). The remaining 18 age-matched control animals received the same type of drinking water without the addition of $\mathrm{Pb}$. In each group, half of the animals were used for morphological study, with the rest used for blood $\mathrm{Pb}$ level measurements. BrdU pulse-chasing study was applied to the 4 and 6 months surviving group. Thus, two BrdU injections $(50 \mathrm{mg} / \mathrm{kg}$, i.p., $8 \mathrm{~h}$ apart, B5002, Sigma-Aldrich, MO, USA) were given after 2 months dosing of $\mathrm{Pb}$ or vehicle.

\section{Measurement of blood $\mathrm{Pb}$ concentration}

After surviving for 2, 4 and 6 months, animals were anesthetized with chloral hydrate $(4 \mathrm{mg} / \mathrm{kg}$, i.p.), and $100 \mu \mathrm{L}$ of blood were collected from the left ventricle of the heart immediately following thoraxitomy. For each analysis, blood $\mathrm{Pb}$ concentration was measured by $\mathrm{BH} 2100$ graphite furnace atomic absorption spectrophotometry (Bohui, Beijing, China) spectrophotometer in the clinical laboratory of the Third Xiangya Hospital of Central South University [51]. The final concentration of blood $\mathrm{Pb}$ was expressed as $\mu \mathrm{g} / \mathrm{dL}$.

\section{Immunohistochemistry}

Animals were anesthetized with chloral hydrate $(4 \mathrm{mg} / \mathrm{kg}$, i.p.) and then perfused with saline followed by $4 \%$ paraformaldehyde in $0.01 \mathrm{M}$ phosphate-buffered saline (PBS) at $4{ }^{\circ} \mathrm{C}$. Brains were dissected and post-fixed by immersion in the same fixative at $4{ }^{\circ} \mathrm{C}$ for $24 \mathrm{~h}$, and were passed in gradual concentrations of sucrose (10\%, $20 \%$ and 30\%) until they sunk. The brains were cut coronally in a cryostat at $30 \mu \mathrm{m}$ and $10 \mu \mathrm{m}$, with sections collected alternatively in two 12-well culture plates. For immunohistochemistry using the avidin-biotin complex method, a set of sections were treated with $1 \% \mathrm{H}_{2} \mathrm{O}_{2}$ in $0.01 \mathrm{M}$ PBS for $30 \mathrm{~min}$, and pre-incubated in 5\% normal horse serum (Sigma-Aldrich, MO, USA) in PBS with $0.3 \%$ Triton $\mathrm{X}-100$ for $1 \mathrm{~h}$ at room temperature, followed by incubation with the goat anti-DCX antibody (polyclone, sc-8066, Santa-Cruz, CA, USA, 1:1000) overnight at $4{ }^{\circ} \mathrm{C}$ [15]. Sections were further reacted with a biotinylated panspecific secondary antibody (horse anti-mouse, rabbit and goat IgG, Vector, CA, USA, 1:400) for $2 \mathrm{~h}$., and subsequently with avidin-biotin complex reagents (Vector, CA, USA, 1:400) for $1 \mathrm{~h}$. Immunoreaction product was visualized using $0.003 \%$ hydrogen peroxide and $0.05 \%$ diaminobenzidine. Three 10-min washes with PBS were used between incubations. Sections were mounted on microslides, allowed to air-dry, and coverslippered. The specificity of this DCX antibody was evaluated previously by multiple groups of investigators [15].

For double immunofluorescence, sections $(10 \mu \mathrm{m}$, thaw-mounted onto slides) were blocked with 5\% donkey serum (Sigma-Aldrich, MO, USA) for $30 \mathrm{~min}$, and then reacted with goat anti-DCX and one of the following antibodies: rat anti-BrdU (monoclonal, MCA2060, Serotec, CA, USA, 1:2000), mouse anti-NeuN (MAB377, Millipore, MA, USA, 1:1000) and rabbit anti caspase-3 (ab3235, Abcam, MA, USA, 1:1000). Sections subjected to BrdU immunolabeling were treated in $1 \mathrm{X} \mathrm{SSC}$ and $50 \%$ formamide for $1 \mathrm{~h}$ at $65{ }^{\circ} \mathrm{C}$, then in $2 \mathrm{~N} \mathrm{HCl}$ for $30 \mathrm{~min}$ at $37{ }^{\circ} \mathrm{C}$ prior to primary antibody incubation. Immunoreaction products were visualized using Alexa Fluor 488 and 594 conjugated secondary antibodies generated in donkey (Jackson ImmunoResearch, PA, USA, 1:200). Fluoro-Jade $C$ stain was carried out according to manufacturer's instruction (AG325, Millipore, MA, USA). In brief, the sections were air dried at room temperature overnight after DCX reaction of immunofluorescence consummated, rehydrated for $2 \mathrm{~min}$ in distilled water and then transferred to the $0.06 \%$ potassium permanganate solution for $10 \mathrm{~min}$. The slides 
were then rinsed for $2 \mathrm{~min}$ in distilled water, transferred to the Fluoro-Jade $\mathrm{C}$ working solution for $10 \mathrm{~min}$ and then rinsed, air dehydrated, xylene cleared and coverslipped with DPX. All sections were counterstained with DAPI (C1002, Beyotime, Beijing, China, 1:10000), washed and counterstained with DAPI before microscopic examination.

\section{Imaging and densitometry}

Immunostained sections were examined and imaged on microscope (BX40, Olympus, Tokyo, Japan) using $4 \times$, $10 \times$ and/or $40 \times$ objective lens. Four cortical areas were arranged for systematic imaging and densitometry, including the frontal cortex, parietal cortex, temporal cortex and occipital cortex. The methodology for cell counting with a Motic pathology picture HD analysis (Motic, Xiamen, China) was described previously [17]. In brief, DCX + cells around layer II were counted in montaged 10x images taken along the cortical surface, and cell density was calculated based on the number of labeled cells underneath unit length of the pial surface (i.e., \# of cells $/ 1 \mathrm{~mm} \times 30 \mu \mathrm{m}$ ). During cell counting, DCX + cells with a longer somal diameter $<10 \mu \mathrm{m}$ (ranged from 5-10 $\mu \mathrm{m}$ ) were marked with a cross sign " $x$ ", whereas those $>10 \mu \mathrm{m}$ (ranged from 10-20 $\mu \mathrm{m}$ ) marked with a small ruler bar (-) of $10 \mu \mathrm{m}$ in length. The number of the cells was then recorded and relative density calculated after obtaining the corresponding pial length of the measured cortical area.

\section{Data analysis}

Data were analyzed using SPSS 10.0 (SPSS, IL, USA). Means of blood Pb levels and DCX + cell densities were calculated for individual and groups of animals. Statistical comparisons were conducted using one-way ANOVA or Student's $t$-test, with $P \leq 0.05$ being considered statistically significance.

\section{Authors' contributions \\ KX, JFH and XXY designed the experiments. KH, MQZ, CLF and KX performed the experiments. HW and DC analyzed the data. KX, LS drafted the manuscript. XXY finalized the manuscript. All authors read and approved the final manuscript. \\ Acknowledgements \\ Supported by National Nature Science Foundation of China (KX; grant number 30900773), Hunan Provincial Nature Science Foundation (KX; grant number 11JJ2020), National University Basic Research Foundation of China (HW; grant number 2010QZZD022) and Central South University (XXY).}

\section{Author details}

${ }^{1}$ Department of Anatomy and Neurobiology, Central South University School of Basic Medical Sciences, Changsha, Hunan 410013, China. ${ }^{2}$ Department of Anatomy, Shaoyang Medical College, Shaoyang, Hunan 422000, China. ${ }^{3}$ Grade 2006, Eight-year Medicine Doctor Program, Central South University Xiangya School of Medicine, Changsha, Hunan 410013, China.

Received: 9 December 2011 Accepted: 6 July 2012

Published: 19 July 2012

\section{References}

1. Fuller R: Lead exposures from car batteries-a global problem. Environ Heal Perspect 2009, 117(12):A535.

2. Shi GT, Chen ZL, Xu SY, Wang L, Zhang J, Li HW, Li LN: Characteristics of heavy metal pollution in soil and dust of urban parks in Shanghai. Huan Jing Ke Xue 2007, 28(2):238-242.

3. Lanphear BP: Childhood lead poisoning prevention: too little, too late. JAMA 2005, 293(18):2274-2276.

4. Brubaker CJ, Dietrich KN, Lanphear BP, Cecil KM: The influence of age of lead exposure on adult gray matter volume. Neurotoxicology 2010, 31(3):259-266

5. Cecil KM, Brubaker CJ, Adler CM, Dietrich KN, Altaye M, Egelhoff JC, Wessel S, Elangovan I, Hornung R, Jarvis K, Lanphear BP: Decreased brain volume in adults with childhood lead exposure. PLoS Med 2008, 5(5):e112.

6. Peters $J$, Kubzansky LD, Ikeda A, Spiro A 3rd, Wright RO, Weisskopf MG, Kim D, Sparrow D, Nie LH, Hu H, Schwartz J: Childhood and adult socioeconomic position, cumulative lead levels, and pessimism in later life: the VA normative aging study. Am J Epidemiol 2011, 174(12):1345-1353.

7. Bellinger D, Sloman J, Leviton A, Rabinowitz M, Needleman HL, Waternaux C: Low-level lead exposure and children's cognitive function in preschool years. Pediatrics 1991, 87(2):219-227.

8. Bellinger D, Stiles K, Needleman HL: Low-level lead exposure intelligence and academic achievement. A long-term follow-up study. Pediatrics 1992, 90(6):855-861.

9. Bleecker ML, Ford DP, Lindgren KN, Hoese VM, Walsh KS, Vaughan CG: Differential effects of lead exposure on components of verbal memory. Occup Environ Med 2005, 62(3):181-187.

10. Carfield RL, Gendle MH, Cory-Slechta DA: Impaired neuropsychological functioning in lead-exposed children. Dev Neuropsychol 2004, 26(1):513-540.

11. Winneke G, Kramaer U: Neurobehavioral aspects of lead neurotoxicity in children. Eru J Pub Health 1997, 5(2):65-69.

12. Gilbert ME, Kelly ME, Samsam TE, Goodman JH: Chronic developmental lead exposure reduced neurogenesis in adult rat hippocampus but does not impair spartial learning. Toxicol Sci 2005, 86(2):365-374.

13. Jaako-Movits K, Zharkovsky T, Romantchik O, Jurgenson M, Merisalu E, Heidmets LT, Zharkovsky A: Developmental lead exposure impairs contextual fear conditioning and reduces and reduces and hippocampus neurogenesis in the rat brain. Int J Dev Neurosci 2005, 23(7):627-635

14. Verina T, Rohde CA, Guilarte TR: Environmental lead exposure during early life alters granule cell neurogenesis and morphology in the hippocampus of young adult rats. Neuroscience 2007, 145(3):1037-1047.

15. Nacher J, Crespo C, McEwen BS: Doublecortin expression in the adult rat telencephalon. Eur J Neurosci 2001, 14(4):629-644.

16. Liu YW, Curtis MA, Gibbons HM, Mee EW, Bergin PS, Teoh HH, Connor B, Dragunow M, Faull RL: Doublecortin expression in the normal and epileptic adult human brain. Eur J Neurosci 2008, 28(11):2254-2265.

17. Xiong K, Luo DW, Patrylo PR, Luo XG, Struble RG, Clough RW, Yan XX: Doublecortin-expressing cells are present in layer II across the adult guinea pig cerebral cortex: partial colocalization with mature interneuron markers. Exp Neurol 2008, 211(1):271-282.

18. Cai $Y$, Xiong K, Chu Y, Luo DW, Luo XG, Yuan XY, Struble RG, Clough RW, Spencer DD, Williamson A, Kordower JH, Patrylo PR, Yan XX: Doublecortin expression in adult cat and primate cerebral cortex relates to immature neurons that develop into GABAergic subgroups. Exp Neurol 2009, 216(2):342-356.

19. Zhang XM, Cai $Y$, Chu Y, Chen EY, Feng JC, Luo XG, Xiong $K$, Struble RG, Clough RW, Patrylo PR, Kordower JH, Yan XX: Doublecortin-expressing cells persist in the associative cerebral cortex and amygdala in aged nonhuman primates. Front Neuroanat 2009, 3:17.

20. Luzzati F, Bonfanti L, Fasolo A, Peretto P: DCX and PSA-NCAM expression identifies a population of neurons preferentially distributed in associative areas of different pallial derivatives and vertebrate species. Cereb Cortex 2009, 19(5):1028-1041.

21. Srikandarajah N, Martinian L, Sisodiya SM, Squier W, Blumcke I, Aronica E, Thom M: Doublecortin expression in focal cortical dysplasia in epilepsy. Epilepsia 2009, 50(12):2619-2628.

22. Bloch J, Kaeser M, Sadeghi Y, Rouiller EM, Redmond DE Jr, Brunet JF: Doublecortin-positive cells in the adult primate cerebral cortex and 
possible role in brain plasticity and development. J Comp Neurol 2011, 519(4):775-789.

23. Marlatt MW, Philippens I, Manders E, Czéh B, Joels M, Krugers H, Lucassen PJ: Distinct structural plasticity in the hippocampus and amygdala of the middle-aged common marmoset (Callithrix jacchus). Exp Neurol 2011, 230(2):291-301.

24. Zhang J, Giesert F, Kloos K, Vogt Weisenhorn DM, Aigner L, Wurst W, Couillard-Despres S: A powerful transgenic tool for fate mapping and functional analysis of newly generated neurons. BMC Neurosci 2011, 11:158.

25. Fung $\mathrm{S}$, Joshi D, Allen KM, Sivagnanasundaram S, Rothmond DA, Saunders R, Noble PL, Webster MJ, Weickert CS: Developmental patterns of doublecortin expression and white matter neuron density in the postnatal primate prefrontal cortex and schizophrenia. PLOS One 2011, 6(9):e25194.

26. Haynes RL, Xu G, Folkerth RD, Trachtenberg FL, Volpe JJ, Kinney HC: Potential neuronal repair in cerebral white matter injury in the human neonate. Pediatr Res 2011, 69(1):62-67.

27. Bernier PJ, Bedard A, Vinet J, Levesque M, Parent A: Newly generated neurons in the amygdala and adjoining cortex of adult primates. Proc Natl Acad Sci USA 2002, 99(17):11464-11469.

28. Pekcec A, Löscher W, Potschka H: Neurogenesis in the adult rat piriform cortex. Neuroreport 2006, 17(6):571-574.

29. Shapiro LA, Ng KL, Kinyamu R, Whitaker-Azmitia P, Geisert EE, Blurton-Jones M, Zhou QY, Ribak CE: Origin, migration and fate of newly generated neurons in the adult rodent piriform cortex. Brain Struct Funct 2007, 212(2):133-148.

30. Guo F, Maeda Y, Ma J, Xu J, Horiuchi M, Miers L, Vaccarino F, Pleasure D: Pyramidal neurons are generated from oligodendroglial progenitor cells in adult piriform cortex. J Neurosci 2010, 30(36):12036-12049.

31. Xiong K, Cai Y, Zhang XM, Huang JF, Liu ZY, Fu GM, Feng JC, Clough RW Patrylo PR, Luo XG, Hu CH, Yan XX: Layer I as a putative neurogenic niche in young adult guinea pig cerebrum. Mol Cell Neurosci 2010, 45(2):180-191

32. Varea E, Belles M, Vidueira S, Blasco-Ibáñez JM, Crespo C, Pastor AM, Nacher J: PSA-NCAM is expressed in immature, but not recently generated, neurons in the adult cat cerebral cortex layer II. Front Neurosci 2011, 5:17.

33. Lamkanfi M, Festjens N, Declercq W, Vanden Berghe T, Vandenabeele P: Caspases in cell survival, proliferation and differentiation. Cell Death Differ 2007, 14(1):44-55.

34. Kutsuna N, Suma T, Takada Y, Yamashita A, Oshima H, Sakatani K, Yamamoto T, Katayama Y: Decrease in doublecortin expression without neuronal cell death in rat retrosplenial cortex after stress exposure. Neuroreport 2012, 23(4):211-215.

35. Yan XX, Najbauer J, Woo CC, Dashtipour K, Ribak CE, Leon M: Expression of active caspase-3 in mitotic and postmitotic cells of the rat forebrain. J Comp Neurol 2001, 433(1):4-22.

36. Chen D, Tong JB, Wang H, Zeng LP, Zhou J, Huang JF, Luo XG: Synaptophysin expression in rat retina following acute high intraocular pressure. Acta Histochem Cytochem 2008, 41(6):173-178.

37. Needleman HL: Low level lead exposure: a continuing problem. Pediatr Ann 1990, 19(13):208-214.

38. Taylor MP, Schniering CA, Lanphear BP, Jones AL: Lessons learned on lead poisoning in children: one-hundred years on from Turner's declaration. J Paediatr Child Health 2010, 47:849-856.

39. Needleman HL, Gatsonic CA: Low-level lead exposure and the IQ of children. A meta-analysis of modern studies. JAMA 1990, 263(5):673-878

40. Canfield RL, Henderson CR Jr, Cory-Slechta DA, Cox C, Jusko TA, Lanphear BP: Intellectual impairment in children with blood lead concentration below 10 microg per deciliter. N Engl J Med 2003, 348(16):1517-1526

41. Chiodo LM, Covington C, Sokol RJ, Hannigan JH, Jannise J, Ager J, Greenwald M, Delaney-Black V: Blood lead levels and specific attention effects in young children. Neurotoxicol Teratol 2007, 29(5):538-546.

42. Goldstein GW: Brain capillaries: a target for inorganic lead poisoning. Neurotoxicology 1984, 5(3):167-175.

43. Goldstein GW: Evidence that lead acts are as a calcium substitute in second messenger metabolism. Neurotoxicology 1993, 14(2-3):97-101.

44. Fox DA, He L, Poblenz AT, Medrano CJ, Blocker YS, Srivastava DL: Lead-induced alterations in retinal cGMP phosphodiesterase trigger calcium overload, mitochondrial dysfunction and rod photoreceptor apoptosis. Toxicol Lett 1998, 102-103:359-361.

45. Flora SJ, Saxena G, Mehta A: Reversal of lead-induced neuronal apoptosis by chelation treatment in rats: role of reactive oxygen species and intracellular Ca (2+). J Pharmacol Exp Ther 2007, 322(1):108-116.

46. Sharifi AM, Mousavi SH, Jorjani M: Effect of chronic lead exposure on pro-apoptotic Bax and anti-apoptotic Bcl-2 protein expression in rat hippocampus in vivo. Cell Mol Neurobiol 2010, 30(5):769-774.

47. Nava-Ruíz C, Alcaraz-Zubeldia M, Méndez-Armenta M, Vergara $P$, Díaz-Ruiz A, Ríos C: Nitric oxide synthase immunolocalization and expression in the rat hippocampus after sub-acute lead acetate exposure in rats. Exp Toxic Pathology 2010, 62(3):311-316.

48. Tavakoli-Nezhad M, Barron AJ, Pitts DK: Postnatal inorganic lead exposure decreases the number of spontaneously active midbrain dopamine neurons in the rat. Neurotoxicology 2001, 22(2):259-269.

49. Oberto A, Marks N, Evans HL, Guidotti A: Lead promotes apoptosis in newborn rat cerebellar neurons: pathological implications. J Pharmacol Exp Ther 1996, 279(1):435-442.

50. Klempin F, Kronenberg G, Cheung G, Kettenmann H, Kempermann G: Properties of doublecortin-(DCX)-expressing cells in the piriform cortex compared to the neurogenic dentate gyrus of adult mice. PLoS One 2011, 6(10):e25760.

51. Huang JF, Huang K, Shang L, Wang H, Yan XX, Xiong K: Beta-amyloid precursor protein cleavage enzyme-1 expression in adult rat retinal neurons in the early period after lead exposure. Neural Regen Res 2011, 6:1045-1051.

doi:10.1186/1471-2202-13-82

Cite this article as: Huang et al:: Chronic lead exposure reduces doublecortin-expressing immature neurons in young adult guinea pig cerebral cortex. BMC Neuroscience 2012 13:82.

\section{Submit your next manuscript to BioMed Central and take full advantage of:}

- Convenient online submission

- Thorough peer review

- No space constraints or color figure charges

- Immediate publication on acceptance

- Inclusion in PubMed, CAS, Scopus and Google Scholar

- Research which is freely available for redistribution 